\title{
Reproductive performance of Ile de France ewes under dietary supplementation before and during the breeding season
}

\section{Desempenho reprodutivo de ovelhas Ile de France submetidas à suplementação alimentar antes e durante a estação de monta}

\author{
Luís Gabriel Alves Cirne ${ }^{1 *}$; Américo Garcia da Silva Sobrinho²; \\ Maria Emilia Franco Oliveira²; José Carlos Barbosa ${ }^{2}$; \\ Gabriel Jorge Carneiro de Oliveira ${ }^{3}$; Adriana Regina Bagaldo ${ }^{3}$; \\ Gleidson Giordano Pinto de Carvalho ${ }^{4}$, Greicy Mitzi Bezerra Moreno ${ }^{5}$
}

\begin{abstract}
The aim of this study was to evaluate the reproductive performance of Ile de France ewes undergoing dietary supplementation before and during the breeding season, with and without association with management conditions (pre-mating shearing). Thirty-six ewes with an average body weight of 66 $\mathrm{kg}$ were used in the experiment. Treatments involved ewes receiving or not receiving concentrate supplementation (flushing), with groups subdivided according to the management condition to which animals were subjected: shearing or lack of it. Thus, ewes were divided into four treatments: flushed and shorn; flushed and unshorn; unflushed and shorn; and unflushed and unshorn. Flushing increased weight gain and body condition score, and when associated with shearing, it promoted anticipation of estrus. Fertility rate $(86.05 \%)$, calving rate $(77.77 \%)$, birth rate $(113.83 \%)$, and type of birth (single: $82.29 \%$ and twin: $17.71 \%)$ were not influenced. Birth weight $(3.96 \mathrm{~kg})$ and prolificacy $(1.25 \%)$ also were not affected. Despite the lack of changes in reproductive traits, flushing adopted during the breeding season associated with shearing anticipated estrus in ewes.
\end{abstract}

Key words: Flushing, management, reproduction, shearing, sheep

\section{Resumo}

O objetivo deste trabalho foi avaliar o desempenho reprodutivo de ovelhas Ile de France submetidas à suplementação alimentar antes e durante a estação de monta associado ou não a condições de manejo (tosquia pré-acasalamento). Foram utilizadas 36 ovelhas, com peso corporal médio de $66 \mathrm{~kg}$. Os tratamentos envolveram ovelhas para receber ou não suplementação concentrada, sendo os grupos ainda subdivididos de acordo com a condição de manejo em que foram submetidos, tosquiados ou não. Assim, as ovelhas foram distribuídas em quatro tratamentos: suplementadas e tosquiadas; suplementadas e não tosquiadas; não suplementadas e tosquiadas e não suplementadas e não tosquiadas. A suplementação alimentar aumentou o ganho de peso e o escore corporal e quando associada à tosquia favoreceu a

${ }^{1}$ Prof. e Pesquisador, Universidade Federal de Roraima, UFRR, Boa Vista, RR, Brasil. E-mail: lgabrielcirne@hotmail.com

2 Profs. e Pesquisadores, Universidade Estadual Paulista, UNESP, Jaboticabal, SP, Brasil. E-mail: americo@fcav.unesp.br; m_ emiliafraoli@yahoo.com.br; jcbarbosa@fcav.unesp.br

${ }^{3}$ Profs. e Pesquisadores, Universidade Federal do Recôncavo da Bahia, UFRB, Cruz das Almas, BA, Brasil. E-mail: gajocaol@, yahoo.com.br; arbagaldo@gmail.com

${ }^{4}$ Prof. e Pesquisador, Universidade Federal da Bahia, UFBA, Salvador, BA, Brasil. E-mail: gleidsongiordano@yahoo.com.br

${ }_{5}^{5}$ Prof. e Pesquisador, Universidade Federal de Alagoas, UFAL, Arapiraca, AL, Brasil. E-mail: greicymitzimoreno@yahoo.com.br

* Author for correspondence 
antecipação do estro. Os índices de fertilidade $(86,05 \%)$, parição $(77,77 \%)$ e natalidade $(113,83 \%)$, assim como o tipo de parto (simples: $82,29 \%$ e duplo: $17,71 \%$ ) não foram influenciados. O peso ao nascer $(3,96 \mathrm{~kg})$ e a prolificidade $(1,25 \%)$ também não foram afetados. Embora não se tenha verificado alteração nas características reprodutivas, a suplementação alimentar na estação de monta associada à tosquia antecipou o estro das ovelhas.

Palavras-chave: Flushing, manejo, ovinos, reprodução, tosquia

\section{Introduction}

The current sheep farming industry is aimed at meat production, which requires high productivity from the herd in terms of reproduction, aiming to increase calving rates. Reproductive efficiency in ewes is determined genetically, but the degree of expression of this genetic potential is influenced by environmental factors such as nutrition.

Reproductive indices, among which are fertility and birth rate, can be improved through proper sanitation, feeding, and reproductive management of ewes before and during mating. The additional weight gain of dams positively affects the occurrence of estrus after the onset of the breeding season and the ovulation rate, which will reflect in better fertility and prolificacy rates for the herd (SELAIVE-VILLARROEL, 1986).

Two to three weeks before the beginning of the breeding season, and over its course, the nutritional level should be improved so as to provide better efficiency and reproductive performance by increasing the fertility rate and consequently birth rate (MORI et al., 2006; VELOSO, 2008). Flushing is a practice aimed at increasing the number of ovulations, improvingfertility in theherd by obtaining a larger number of multiple births (CHAGAS et al., 2007). The first month after fertilization is critical for embryo survival, and it is important to extend the nutritional flushing for 30 days after the mount, which is the necessary time for the implantation of the embryo in the uterus (NRC, 2007; NOGUEIRA et al., 2011). Although the nutritional flushing is a simple and known practice, the necessary care to make this management efficient is often not taken, which requires further research to consolidate this technique and obtain better reproductive indices.
Besides feeding, benefits in reproductive efficiency can be obtained from management practices such as the shearing of sheep pre-mating. When shorn, sheep require a greater energy uptake to control body temperature, and thus they tend to consume more to meet this caloric demand. Part of the nutrients is stored, which provides a better body condition and consequently better reproductive performance.

In this regard, the present study aimed to determine the best management strategy for Ile de France ewes subjected to concentrate supplementation (flushing), with or without association with premating shearing.

\section{Material and Methods}

The experiment was conducted in the Sheep Farming Unit at the Department of animal Science at FCAV Unesp, Jaboticabal Campus, SP, Brazil (21 ${ }^{\circ} 15$ '22" S latitude and 48 $18^{\circ} 58^{\prime \prime} \mathrm{W}$ latitude; $595 \mathrm{~m}$ altitude). Thirty-six Ile de France ewes with an average body weight of $66 \mathrm{~kg}$ at the beginning of the study were used. Treatments consisted of sheep receiving or not receiving concentrate supplementation (flushing) for three weeks before the beginning of the breeding season and three weeks afterwards, totaling six weeks of dietary supplementation. The two groups of animals, flushed or unflushed, were also subdivided according to the management condition to which they were subjected, shorn or not shorn at the beginning of flushing (three weeks prior to the start of the breeding season). Thus, all sheep were distributed into four treatments: flushed and shorn; flushed and unshorn; unflushed and shorn; and unflushed and unshorn. 
The breeding season lasted 60 days, beginning on November 7, 2011 and ending on January 6, 2012. An 18-month old sire with $80 \mathrm{~kg}$ body weight remained with the sheep from the four treatments during the daytime and separated from the females in the late evening, when they received (or did not receive) flushing in collective troughs.

Animals were managed on a 2-ha Cynodon dactylon cv. Vaquero grass pasture (Table 1), divided into five 0.4-ha paddocks, containing salt troughs and drinkers, under intermittent stocking, with a fixed rest period of 20 days, receiving corn silage (Table 2) with or without (500 g/animal/ day) concentrate supplementation (Table 3) in the late afternoon. Sheep were kept in shelters at night, following the management procedures typically adopted for the animals of the institution. Animals were dewormed (or not) at the beginning and throughout the breeding season, according to the count of eggs per gram of feces.

Table 1. Chemical composition of Cynodon dactylon cv. Vaquero pasture.

\begin{tabular}{lc}
\hline Item & \% dry matter \\
\hline Dry matter & 22.12 \\
Mineral matter & 6.68 \\
Crude protein & 16.42 \\
Ether extract & 2.20 \\
Lignin & 3.69 \\
Neutral detergent fiber & 54.97 \\
Acid detergent fiber & 28.34 \\
\hline
\end{tabular}

Table 2. Chemical composition of corn silage.

\begin{tabular}{lc}
\hline Item & \% dry matter \\
\hline Dry matter & 27.68 \\
Mineral matter & 5.90 \\
Crude protein & 9.23 \\
Ether extract & 3.55 \\
Lignin & 2.25 \\
Neutral detergent fiber & 36.28 \\
Acid detergent fiber & 21.26 \\
\hline
\end{tabular}

Table 3. Centesimal composition of ingredients and chemical composition of the concentrate supplement.

\begin{tabular}{|c|c|}
\hline Ingredient & $\%$ dry matter \\
\hline Ground corn & 60.00 \\
\hline Soybean meal & 15.00 \\
\hline Wheat bran & 20.00 \\
\hline Mineral $\operatorname{mix}^{1}$ & 5.00 \\
\hline \multicolumn{2}{|l|}{ Chemical composition } \\
\hline Dry matter & 89.38 \\
\hline Mineral matter ${ }^{2}$ & 8.09 \\
\hline Crude protein ${ }^{2}$ & 15.43 \\
\hline Ether extract ${ }^{2}$ & 5.02 \\
\hline Neutral detergent fiber ${ }^{2}$ & 21.37 \\
\hline Acid detergent fiber ${ }^{2}$ & 6.87 \\
\hline Total carbohydrates ${ }^{2}$ & 71.52 \\
\hline Non-fiber cabohydrates ${ }^{2}$ & 50.15 \\
\hline Gross energy (Mcal/kg DM) & 4.36 \\
\hline
\end{tabular}

'Provides per kilogram of product: calcium $120 \mathrm{~g}$, chlorine $90 \mathrm{~g}$, cobalt $10 \mathrm{mg}$, copper $50 \mathrm{mg}$, sulfur $34 \mathrm{~g}$, iron $1064 \mathrm{mg}$, phosphorus $50 \mathrm{~g}$, iodine $25 \mathrm{mg}$, magnesium $54 \mathrm{~g}$, manganese $1,500 \mathrm{mg}$, selenium $20 \mathrm{mg}$, sodium $62 \mathrm{~g}$, zinc $1,600 \mathrm{mg}$, fluorine (max) $0.73 \mathrm{~g}$, vitamin A 100,000 IU, vitamin D3 40,000 IU, and vitamin E $600 \mathrm{IU}$.

${ }^{2}$ in $\% \mathrm{DM}$.

During the experimental period, samples of ingredients and concentrate and of the supplied feed were collected to determine the dry matter (DM), mineral matter (MM), ether extract (EE), and gross energy levels (SILVA; QUEIROZ, 2002). The total nitrogen content of the samples was obtained by the Dumas combustion method, using a LECO FP-528 LC (ETHERIDGE et al., 1998) analyzer, with the result multiplied by 6.25 to obtain the total crude protein (CP) content. Concentrations of lignin, neutral detergent fiber corrected for ash and protein (NDFap), and acid detergent fiber (ADF) were determined according to Van Soest (1994) and as recommended by the manufacturer of ANKOM Technology ${ }^{\circledR}$, using ANKOM bags. Total carbohydrates (TC) were calculated by the following equation: $\mathrm{TC}=100$ $(\% \mathrm{CP}+\% \mathrm{EE}+\% \mathrm{MM})$. Non-fiber carbohydrates were estimated by adapting the formula proposed 
by Hall (2000): NFC $=100-[(\% \mathrm{CP}-\mathrm{CPu}+\mathrm{U})+$ $\% \mathrm{EE}+\% \mathrm{MM}+\% \mathrm{NDFap}$, where $\mathrm{CPu}$ is the $\mathrm{CP}$ content from urea (\%); and $\mathrm{U}$ is the urea content $(\%)$.

To identify the ewes that manifested estrus and were mounted, the sire was marked daily with a paste prepared by mixing powder paint with soybean oil, which was smeared near the prepuce, and when the sire mounted the ewes, their rump would be marked; mounts were recorded daily. The paint color was changed every 15 days (yellow, green, red, and blue) to facilitate identification and monitoring throughout the breeding season.

The following ewes' body traits were evaluated: body weight, average daily weight gain, body condition score, and biometric measurements (ileal and ischial lengths and withers and rump heights). Body weight and average daily weight gain were evaluated at the beginning, 21, and 42 days after the start of supplementation, and at the end of the breeding season, with body condition scores and biometric measurements obtained 21 days after the beginning of supplementation and at the end of the breeding season. Body condition score was determined according to the method described by Ribeiro et al. (2003), by assigning scores of 1 to 5 , in which 1 corresponded to very lean animals, and 5 , to obese animals. Measurements were taken with the animals standing on a flat, horizontal surface, always by the same person, aiming to reduce errors originating from the evaluator.

The following reproductive traits were evaluated: fertility (mounted ewes/ewes in breeding season), calving (lambed ewes/ewes in breeding season), prolificacy (lambs born/lambed ewes), percentage of single or twin births, and lamb birth weight.

The experimental design was completely randomized, in a $2 \times 2$ factorial arrangement with four replicates (corn silage with and without flushing, and ewes shorn and unshorn) and nine replicates, totaling 36 experimental plots. Results were evaluated by analyses of variance utilizing AgroEstat statistical software (BARBOSA; MALDONADO JÚNIOR, 2013), at 5\% significance level. When significances were detected between treatments for the different studied variables, they were compared by Tukey's test, at the same significance level. For the fertility, calving, and birth rates and type of birth, the chi-squared test was applied to the contingency table, using the PROC GLM procedure of SAS (2009) statistical software, at 5\% significance level.

\section{Results and Discussion}

The dietary supplementation $\times$ management condition interaction had no effect on the variables body weight, average daily weight gain, and body condition score of the dams; data were discussed separately (Table 4). Unshorn animals had higher $(\mathrm{P}<0.05)$ body weights at the beginning and 21 and 42 days after the start of concentrate supplementation, which was attributed to the weight of their wool. The fact that the unshorn ewes were managed on pasture in the rainy season might have contributed to this result, since, according to Erhardt et al. (1976), wool can absorb up to $40 \%$ moisture compared with its dry weight, hence why it is considered the most hygroscopic of fibers. 
Table 4. Body weight $(\mathrm{kg})$, average daily weight gain $(\mathrm{kg} /$ day), and body condition score of ewes during the breeding season according to flushing and shearing management.

\begin{tabular}{|c|c|c|c|c|c|c|c|c|}
\hline \multirow{2}{*}{ Variable } & \multicolumn{2}{|c|}{ Flushing $(\mathrm{F})$} & \multicolumn{2}{|c|}{ Management (M) } & \multicolumn{3}{|c|}{$\operatorname{Pr}>\mathrm{F}$} & \multirow{2}{*}{ SEM } \\
\hline & Yes & No & Shorn & Unshorn & $\mathrm{F}$ & $\mathrm{M}$ & $\mathrm{F} \times \mathrm{M}$ & \\
\hline BW-0 day & 67.17 & 63.00 & 60.76 & 66.62 & 0.372 & 0.072 & 0.566 & 2.280 \\
\hline BW-21 days & 64.52 & 60.95 & $56.76 \mathrm{a}$ & $68.70 \mathrm{~b}$ & 0.420 & 0.010 & 0.625 & 4.376 \\
\hline BW-42 days & 68.22 & 61.76 & $59.67 \mathrm{a}$ & $70.32 b$ & 0.142 & 0.019 & 0.771 & 4.277 \\
\hline BW-60 days & 69.40 & 62.50 & 61.84 & 70.06 & 0.099 & 0.052 & 0.675 & 4.057 \\
\hline ADG-21 days & $0.123 \mathrm{a}$ & $0.026 \mathrm{~b}$ & 0.053 & 0.095 & 0.000 & 0.086 & 0.195 & 0.023 \\
\hline ADG-42 days & $0.112 \mathrm{a}$ & $0.026 \mathrm{~b}$ & 0.090 & 0.048 & 0.000 & 0.051 & 0.214 & 0.020 \\
\hline ADG-60 days & 0.011 & -0.001 & $0.031 \mathrm{a}$ & $-0.020 b$ & 0.538 & 0.019 & 0.359 & 0.020 \\
\hline BCS-21 days & $3.81 \mathrm{a}$ & $3.25 \mathrm{~b}$ & 3.56 & 3.50 & 0.004 & 0.733 & 0.733 & 0.181 \\
\hline BCS-60 days & 3.68 & 3.31 & 3.50 & 3.50 & 0.053 & 1.000 & 0.053 & 0.186 \\
\hline
\end{tabular}

Means followed by different letters in the row differ according to Tukey's test at $5 \%$ probability level.

$\mathrm{BW}=$ body weight; $\mathrm{ADG}=$ average daily weight gain; $\mathrm{BCS}=$ body condition score; $\mathrm{Pr}>\mathrm{F}=$ probability; $\mathrm{SEM}=$ standard error of the mean.

The average daily weight gains (ADG) at the beginning (21 days) and end of supplementation (42 days), as well as the body condition score 21 days after the beginning of flushing were higher $(\mathrm{P}<0.05)$ in the flushed animals (Table 4). The greater ADG of supplemented ewes might have resulted from their higher nutrient intake. The results of this study are similar to those reported by Mori et al. (2006) and Veloso (2008), who, evaluating the reproductive performance of ewes at the beginning and during the breeding season, observed higher ADG in the supplemented ones; and by Chaturvedi et al. (2003), who studied the effect of supplementation on performance and production of Malpura and Kheri ewes on a natural pasture during the end of gestation and in early lactation, and observed a higher ADG in the supplemented animals.

No difference $(\mathrm{P}>0.05)$ from the supplementation $\times$ management condition interaction was detected for the biometric measurements. Likewise, flushing did not affect $(\mathrm{P}>0.05)$ these variables (Table 5).

Shearing influenced $(\mathrm{P}<0.01)$ the ewes' biometric measurements, with higher values for ischial and ileal length and withers and rump heights found in the unshorn animals, probably because of the wool, which underestimated the measurements, since ewes had similar weights before shearing.

Table 5. Biometric measurements $(\mathrm{cm})$ of ewes during the breeding season according to flushing and shearing management.

\begin{tabular}{|c|c|c|c|c|c|c|c|c|}
\hline \multirow{2}{*}{ Variable } & \multicolumn{2}{|c|}{ Flushing $(\mathrm{F})$} & \multicolumn{2}{|c|}{ Management (M) } & \multicolumn{3}{|c|}{$\operatorname{Pr}>\mathrm{F}$} & \multirow{2}{*}{ SEM } \\
\hline & Yes & No & Shorn & Unshorn & $\mathrm{F}$ & $\mathrm{M}$ & $\mathrm{F} \times \mathrm{M}$ & \\
\hline ILIL-21 days & 25.09 & 23.90 & $23.37 \mathrm{a}$ & $25.62 b$ & 0.107 & 0.003 & 0.224 & 0.714 \\
\hline ILIL-60 days & $24.92 \mathrm{a}$ & $23.39 b$ & $22.24 \mathrm{a}$ & $25.07 \mathrm{~b}$ & 0.025 & 0.008 & 0.429 & 0.645 \\
\hline ISQL-21 days & 24.69 & 23.51 & $22.93 \mathrm{a}$ & $25.27 b$ & 0.079 & 0.001 & 0.423 & 0.645 \\
\hline ISQL- 60 days & 24.44 & 23.58 & $23.04 \mathrm{a}$ & $24.98 b$ & 0.144 & 0.002 & 0.763 & 0.575 \\
\hline WH-21 days & 103.25 & 100.81 & $95.06 \mathrm{a}$ & $109.00 \mathrm{~b}$ & 0.307 & 0.001 & 0.692 & 2.343 \\
\hline WH- 60 days & 103.62 & 100.31 & $94.37 \mathrm{a}$ & $109.56 b$ & 0.209 & 0.001 & 0.942 & 2.577 \\
\hline RH-21 days & 100.06 & 98.87 & $91.93 \mathrm{a}$ & $107.00 \mathrm{~b}$ & 0.636 & 0.001 & 0.784 & 2.483 \\
\hline RH- 60 days & 99.25 & 96.00 & $91.68 \mathrm{a}$ & $103.56 \mathrm{~b}$ & 0.326 & 0.001 & 0.471 & 3.256 \\
\hline
\end{tabular}

Means followed by different letters in the row differ according to Tukey's test at $5 \%$ probability level.

$\mathrm{CILI}=$ ileal length; CISQI = ischial length; $\mathrm{WH}=$ wither height; $\mathrm{RH}=$ rump height; $\mathrm{Pr}>\mathrm{F}=$ probability; $\mathrm{SEM}=$ standard error of the mean. 
Of the shorn ewes that received flushing, $77.78 \%$ manifested estrus and were mounted on the first 15 days of the breeding season, and $55.55 \%$ of supplemented unshorn ewes also displayed estrus in the same periods. The others showed estrus up to 30 days from the beginning of the breeding season (Figure 1), which allows us to infer that shearing, when associated with supplementation, promoted the anticipation of estrus in the breeding season, which can reduce the calving interval, thereby improving the reproductive and productive efficiencies of the herd. Ewes that did not receive flushing manifested estrus throughout their entire breeding season (Figure 1). All ewes that manifested estrus during the breeding season were fertilized, according to the fertility rates (Table 6), verified by the lack of repetition of heat after mounting.

Table 6. Fertility, calving, and birth rates and type of birth in ewes according to flushing and shearing management.

\begin{tabular}{|c|c|c|c|c|c|}
\hline \multirow{2}{*}{ Treatment } & \multicolumn{3}{|c|}{ Rate $(\%)$} & \multicolumn{2}{|c|}{ Type of birth (\%) } \\
\hline & Fertility & Calving & Birth & Single & Twin \\
\hline Flushed and shorn & 77.70 & 77.77 & 128.57 & 83.33 & 16.67 \\
\hline Flushed and unshorn & 100.00 & 88.88 & 137.50 & 62.50 & 37.50 \\
\hline P-value & 1.000 & 1.000 & 1.000 & \multicolumn{2}{|c|}{0.580} \\
\hline Shorn & 77.70 & 66.66 & 75.00 & 100.00 & 0.00 \\
\hline Unshorn & 88.80 & 77.77 & 114.28 & 83.33 & 16.67 \\
\hline P-value & 1.000 & 0.696 & 1.000 & \multicolumn{2}{|c|}{1.000} \\
\hline
\end{tabular}

The reproductive response of the ewes subjected to flushing and pre-mating shearing was possibly related to their higher nutrient intake, because feeding quantitatively and qualitatively inappropriate diets is among the main causes of prolonged anestrus (SHORT; ADAMS, 1988). This result agrees with those reported by Leal et al. (2010), who evaluated the reproductive performance of Santa Inês ewes receiving dietary supplementation and found a rapid return to estrus; by Sabra and Hassan (2008), who found an extension of estrus in animals when studying the reproductive performance of Barki ewes subjected to flushing; and by Islam et al. (2007), who reported an improvement in the reproductive efficiency of Corriedale ewes also subjected to flushing.

Figure 1. Ewes in estrus and occurrence of mount throughout the breeding season. FS = flushed and shorn; FU = flushed and unshorn; US = unflushed and shorn; UU = unflushed and unshorn.

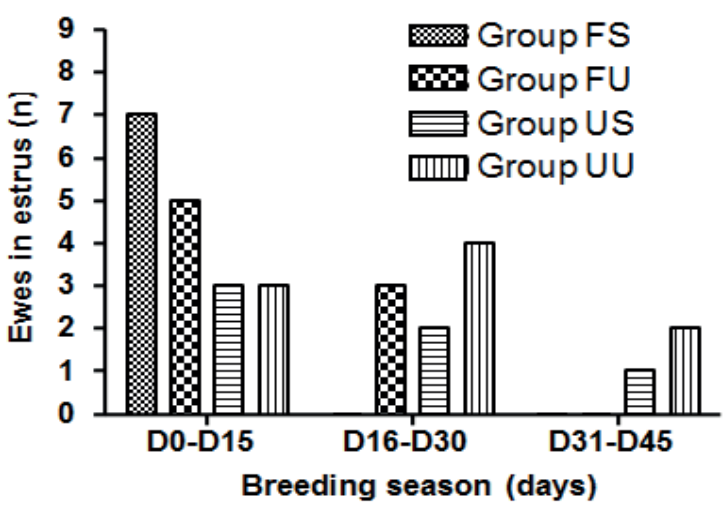


Regarding the fertility, calving, and birth rates, as well as the type of birth, no influences $(\mathrm{P}>0.05)$ of flushing and shearing (Table 6) were found on these variables, probably as a result of the good body condition score of the ewes (Table 4), which was above 3.0, considered good according to Mori et al. (2006). The best results with flushing are obtained in animals that have undergone some nutritional deficiency before the breeding season, whose nutritional requirement was not met (negative energy balance), with body condition scores of 2.0 to 2.5 (FREITAS, 2008).

The mean values of 86.05 and $77.77 \%$ for the fertility and calving rates, respectively, are close to the $79.20 \%$ and $73.70 \%$ reported by Chaturvedi et al. (2006) in Malpura ewes subjected to flushing on natural pasture. The average birth rate of $113.83 \%$ was similar to the $118.20 \%$ reported by Mori et al. (2006), who studied the reproductive performance of Ile de France ewes supplemented before and during the breeding season; and close to the $120.84 \%$ found by Sabra and Hassan (2008), evaluating the reproductive performance of Barki ewes subjected to flushing.

For type of birth, irrespective of flushing and shearing, ewes had a higher percentage of single births, probably because they already had a good body condition score in the beginning of the breeding season. Evaluating the reproductive performance of Corriedale ewes with different body condition scores subjected to supplementation, Gonçalves et al. (2008) also recorded greater occurrence of single births in animals with body condition score above 3.0.

The birth weight of the lambs and the prolificacy of the ewes also were not affected $(\mathrm{P}>0.05)$ by the flushing $\times$ management condition interaction, with a trend towards greater prolificacy observed in the flushed animals (Table 7).

Table 7. Lamb birth weight and ewe prolificacy according to flushing and shearing management.

\begin{tabular}{|c|c|c|c|c|c|c|c|c|}
\hline \multirow{2}{*}{ Variable } & \multicolumn{2}{|c|}{ Flushing $(\mathrm{F})$} & \multicolumn{2}{|c|}{ Management $(\mathrm{M})$} & \multicolumn{3}{|c|}{$\operatorname{Pr}>\mathrm{F}$} & \multirow{2}{*}{ SEM } \\
\hline & Yes & No & Shorn & Unshorn & $\mathrm{F}$ & M & $\mathrm{F} \times \mathrm{M}$ & \\
\hline Birth weight $(\mathrm{kg})$ & 4.11 & 3.81 & 3.71 & 4.21 & 0.509 & 0.284 & 0.106 & 0.449 \\
\hline Prolificacy (\%) & 1.40 & 1.10 & 1.20 & 1.30 & 0.153 & 0.623 & 0.623 & 0.200 \\
\hline
\end{tabular}

$\operatorname{Pr}>\mathrm{F}=$ probability; $\mathrm{SEM}=$ standard error of the mean .

As regards birth weight, the results observed in this study were similar to those reported by Chaturvedi et al. (2006), who did not find an effect of flushing on Malpura ewes on the birth weight of the lamb; and contrary to those found by Chaturvedi et al. (2003), who, studying the effect of supplementation on performance and production of Malpura and Kheri ewes on natural pasture, recorded higher birth weights in lambs from ewes supplemented during the end of gestation and beginning of lactation due to the low pasture quality. The average prolificacy of 1.25 was similar to the 1.30 described by Veloso (2008), who evaluated the productive and reproductive performance of ewes subjected to different flushing systems. The average prolificacy of 1.40 of the supplemented ewes was similar to the 1.37 obtained in Corriedale ewes by Mori et al. (2006). Prolificacy rates are important in the production system because, as they relate the number of lambs born per ewe, they contribute to improving the reproductive efficiency (SOUZA, 2007), increasing the scale of production of animals for reproduction and slaughter. 


\section{Conclusions}

Flushing Ile de France ewes before and during the breeding season increased weight gain and body condition score, and, when associated with shearing, it anticipated estrus in the animals.

\section{References}

BARBOSA, J. C.; MALDONADO JÚNIOR, W. AgroEstat - Sistema para análises estatísticas de ensaios agronômicos. Versão 1.1.0.668. Jaboticabal: [s.n.], 2013.

CHAGAS, A. C. S.; OLIVEIRA, M. C. S.; FERNANDES, L. B.; MACHADO, R.; ESTEVES, S. N.; SALES, R. L.; BARIONI JUNIOR, W. Ovinocultura: controle da verminose, mineralização, reprodução e cruzamentos. São Carlos: EMBRAPA, 2007. 44 p.

CHATURVEDI, O. H.; BHATTA, R.; SANTRA, A.; MISHRA, A. S.; MANN, J. S. Effect of supplementary feeding of concentrate on nutrient utilization and production performance of ewes grazing on community rangeland during late gestation and early lactation. Asian-Australasian Journal of Animal Sciences, Seoul, v. 16, n. 7, p. 983-987, 2003.

CHATURVEDI, O. H.; BHATTA, R.; VERMA, D. L.; SINGH, N. P. Effect of flushing on nutrient utilization and reproductive performance of ewes grazing on community rangeland. Asian-Australasian Journal of Animal Sciences, Seoul, v. 19, n. 4, p. 521-525, 2006.

ERHARDT, T.; BLÜMCKE, A.; BÜGER, W.; MÄRCKILN, M.; QUINZLER, G. Curso técnico têxtil: física e química aplicada, fibras têxteis, tecnologia. São Paulo: EPU/EDUSP, 1976. v. 1.

ETHERIDGE, R. D.; PESTI, G. M.; FOSTER, E. H. A comparison of nitrogen values obtained utilizing the Kjeldahl nitrogen and Dumas combustion methodologies (Leco CNS 2000) on samples typical of an animal nutrition analytical laboratory. Animal Feed Science and Technology, Amsterdam, v. 73, n. 1, p. 2128, 1998.

FREITAS, V. J. F. Influência da nutrição para o sucesso das biotécnicas reprodutivas utilizadas em caprinos e ovinos. In: CONGRESSO BRASILEIRO DE NUTRIÇÃO ANIMAL, 1., 2008, Fortaleza. Anais... Fortaleza: SEBRAE-CE, 2008. CD-ROM.

GONÇALVES, M.; OSÓRIO, J. C. S.; OSÓRIO, M. T. M.; PRADIÉE, J.; VILANOVA, M.; ESTEVES, R. M.; KESSLER, J. D.; ARNONI, R. K.; FERREIRA, O. G.; CORREA, G. Desempenho reprodutivo de ovelhas
Corriedale com distintas condições corporais submetidas ao flushing. In: CONGRESSO BRASILEIRO DE MEDICINA VETERINÁRIA, 35., 2008, Gramado. Anais... Gramado: Conbravet, 2008. CD-ROM.

HALL, M. B. Neutral detergent-soluble carbohydrates: nutritional relevance and analysis. Gainesville: University of Florida, 2000. $76 \mathrm{p}$.

ISLAM, R.; BHAT, A. S.; SARKAR, T. K.; SINGH, P. K.; KHAN, M. Z. Effect of flushing on reproductive performance of corriedale ewes. The Indian Journal of Small Ruminants, New Delhi, v. 13, n. 1, p. 55-60, 2007.

LEAL, T. M.; NUNES, J. F.; SALGUEIRO, C. C. M.; SALMITO-VANDERLEY, C. S. B.; NASCIMENTO, H. T. S.; MOURA, A. A. A. Retorno ao estro pós-parto em ovelhas da raça Santa Inês: influência do manejo alimentar e da alimentação. In: XIMENES, L.; MARTINS, G. A.; MORAIS, O. R.; COSTA, L. S. A.; NASCIMENTO, J. L. S. Ciência e tecnologia na pecuária de caprinos e ovinos. Fortaleza: Banco do Nordeste do Brasil, 2010. p. 560-577.

MORI, R. M.; RIBEIRO, E. L. A.; MIZUBUTI, I. Y.; ROCHA, M. A.; SILVA, L. D. F. Desempenho reprodutivo de ovelhas submetidas a diferentes formas de suplementação alimentar antes e durante a estação de monta. Revista Brasileira de Zootecnia, Viçosa, MG, v. 35, n. 3, p. 1122-1128, 2006.

NATIONAL RESEARCH COUNCIL - NRC. Nutrients requirements of sheep. Washington: National Academies Press, 2007. 362 p.

NOGUEIRA, D. M.; ELOY, M. A.; SÁ, C. O.; LOPES JÚNIOR, E. S.; SALLES, H. O.; SÁ, J. L.; SOUSA, P. H. F. Manejo Reprodutivo. In: VOLTOLINI, T. V. Produção de ovinos e caprinos no semiárido. Petrolina: Embrapa Semiárido, 2011. p. 385-420.

RIBEIRO, L. A. O.; FONTANA, C. S.; WALD, V. B.; GREGORY, R. M.; MATTOS, R. C. Relação entre a condição corporal e a idade das ovelhas no encarneiramento com a prenhez. Ciência Rural, Santa Maria, v. 33, n. 2, p. 357-361, 2003.

SABRA, H. A.; HASSAN, S. G. Effect of new regime of nutritional flushing on reproductive performances of Egyptian Barki Ewes. Global Veterinaria, Dubai, v. 2, n. 1, p. 28-31, 2008.

STATISTICAL ANALYSIS SYSTEM INSTITUTE SAS. Statistical Analysis System user's guide. Version 9.2. Cary: SAS Institute, 2009.

SELAIVE-VILLARROEL, A. B. Manejo reprodutivo dos ovinos. In: SIMPÓSIO PARANAENSE DE OVINOCULTURA, 3., 1986, Guarapuava. Anais... Guarapuava: OVINOPAR, 1986. p. 62-71. 
SHORT, R. E.; ADAMS, D. C. Nutritional and hormonal interrelationship in beef cattle reproduction. Canadian Journal of Animal Science, Ottawa, v. 68, n. 1, p. 29-39, 1988.

SILVA, D. J.; QUEIROZ, A. C. Análise de alimentos: métodos químicos e biológicos. 5. ed. Viçosa, MG: Imprensa Universitária, 2002. 235 p.

SOUZA, D. A. Utilizando indices de desempenho: parte II. Piracicaba: Farmpoint, 2007. Disponível em: $<$ http://www.farmpoint.com.br/cadeia-produtiva/dicasde-sucesso/utilizando-indices-de-desempenho-parte-ii41536n.aspx>. Acesso em: 10 set. 2015.
VAN SOEST, P. J. Nutritional ecology of the ruminant. New York: Cornell University Press, 1994. 476 p.

VELOSO, J. L. O. Desempenho produtivo e reprodutivo de ovelhas submetidas a diferentes sistemas de flushing. 2008. Dissertação (Mestrado em Zootecnia) - Universidade Estadual do Sudoeste da Bahia, Itapetinga. 
